\title{
The „Lost" and The „Born"Generations: two Perspectives on the WWI and a short comparison of Western and Eastern Great War literature
}

\author{
Eugenijus Žmuida \\ The Institute of Lithuanian Literature and Folklore
}

\begin{abstract}
The Great War was not only the first modern war (in terms of technology) in the history of mankind but also the War involving the greatest number of educated people. For the first time, there was such an intense reflection of the anti-humanity, meaninglessness, and absurdity of war captured in war memoirs, letters, and fiction. For the first time, such an abundance of war literature was created, having its poetics and ideology. This phenomenon is mainly known as the literature of "The Lost Generation" associated with the Western Front and Western authors. But the same long and troublesome War was fought in Central and Eastern Europe. Here this War was even more important and its results more significant, as it resulted in the collapse of four great empires. Many nations declared independence, created their states - independent republics. Participants and witnesses of the Eastern Front also left the war literature. In my paper, I would like to pay attention to this mostly unknown chapter of the World war literature and using the case of well-known (for me) Lithuanian literature as one of Eastern Europe representatives to do some comparisons with the literature of Lost Generation (not so much in artistic expression and style but empathy). We can conditionally divide all military literature into two parts: written during and after the war. Comparing the first (war) period and avantgarde poetry (even after the war) we will find more similarities than differences. But the novels and memoirs written after the war reveal completely different attitudes. In my report, I would like to stop at a more detailed comparison of these two directions of the Great War literature and question the notion that the entire generation has returned from the War as "lost."
\end{abstract}

Keywords: Great War, war and post war literature, memory, comparison, 